\title{
Hypophysis. From outgrowth, to ocular disorder to pituitary gland
}

\author{
Konstantinos Laios, ${ }^{1}$ George Androutsos, ${ }^{2}$ Maria Piagkou, ${ }^{3}$ Marilita M. Moschos ${ }^{1,2}$
}

${ }^{1} 1^{\text {st }}$ Department of Ophthalmology, Medical School, National and Kapodistrian University of Athens, ${ }^{2}$ Biomedical Research Foundation, Academy of Athens, ${ }^{3}$ Department of Anatomy, Medical School, National and Kapodistrian University of Athens, Athens, Greece

Dear Editor,

In ancient Greek the term vंđó $\varphi v \sigma \iota \varsigma$ meant literally something growing from below, the word being composed of the two elements hypo (Greek: vitó, below) and phyomai ( $\varphi v ́ o \mu \alpha 1$, grow). In ancient Greek medical literature we find this term with various meanings. ${ }^{1}$

Galen $\left(2^{\text {nd }} \mathrm{c} . \mathrm{AD}\right)$ used it to describe a progressive outgrowth, as of hair (De methodo medendi libri xiv 10.1015.6), the nails (De anatomicis administrationibus libri ix 2.337.16) of hard skin or of the tendons, the ancient physician believing that the hardness of a tissue caused its emergence (De usu partium 3.110.18, 3.111.6). Pseudo-Galen $\left(2^{\text {nd }} c\right.$ c. AD) used the term hypophysis to describe the ocular diseases of trichiasis and ectropion, the former referring to an ingrowth of the eyelashes and the latter to a turning outward of the lower eyelid. The same concept of trichiasis is also found in the works of the Byzantine physicians Aetius of Amida (6 ${ }^{\text {th }}$ c. AD) (Iatricorum

Key words: Hypophysis, pituitary gland, Etymology, Ancient Greek medicine, Samuel Thomas von Sömmerring

Address for correspondence:

Konstantinos Laios PhD, 1 Athinodorou street, Kato Petralona, 118 53, Athens, Greece; Tel.: +30 6947091434,

Fax:+30 2103474338, e-mail: konstlaios@gmail.com

Received: 02-01-2017, Accepted: 28-01-2017 liber vii 68.8$)$ and Alexander Trallianus ( $\left.6^{\text {th }} \mathrm{c} . \mathrm{AD}\right)$ (De oculis libri tres 146.19).

The pituitary gland was not designated by ancient Greek physicians as the hypophysis but as the A $\delta \dot{\eta} v$ (gland), which was described as having the shape of a flattened sphere, according to the words of Galen (De usu partium 3.693.20). Andreas Vesalius (1514-1564) was the first to translate into Latin the ancient Greek term 'A $\delta \dot{\eta} v$ used by Galen to describe the hypophysis, his definition, however, combining the name of the organ with its supposed quality of oozing mucus, thereby introducing the Latin term glandula pituitaria (a gland which oozes mucus). ${ }^{2}$

It was Samuel Thomas von Sömmerring (17551830) who in 1778 reintroduced the ancient Greek term hypophysis, now used only in reference to the pituitary gland, employing the specific term hypophysis cerebri, in his work Dissertatio de basi encephali et originibus nervorum cranio egredentium libri quinque ("The origins of the nervous system and the brain in the skull base", a dissertation in five volumes). ${ }^{3}$ The term reintroduced by Sömmerring had the same meaning as did the ancient term, that of an outgrowth, but it was now assigned to this specific organ. Nevertheless, Sömmerring simultaneously also used the term appendix cerebri, denoting a cerebral appendage, which in fact is another way to describe the shape and form of this organ in relation to the rest of the brain, and which can be considered as an alternative of the term hypophysis. ${ }^{4}$ Since the $19^{\text {th }}$ century both 
terms, the Latin glandula pituitaria, in its translated form in each language whether European or otherwise, and the term hypophysis have been in use up until the present day to identify this small but very important organ. ${ }^{5}$

\section{CONFLICT OF INTEREST}

All the authors declare that there is no conflict of interest.

\section{REFERENCES}

1. Liddell HG, Scott R, 1940 A Greek-English Lexicon. revised and augmented throughout by Sir Henry Stuart Jones with the assistance of Roderick McKenzie. Oxford: Clarendon Press.

2. Vesalius A, 1543 Andreae Vesalii Bruxellensis De humani corporis fabrica libri septem. Basileæ: Ex officina Ioannis Oporini.

3. Sommerring ST, 1778 De basi encephali et originibus nervorum cranio egredentium libri quinque. Gottingae: Vadnehoeck.

4. Schreger CHTh, 1805 Synonymia anatomica. Synonymik der anatomischen Nomenclatur. Fürth: im Bureau für Literatur.

5. Hyrtl J, 1880 Onomatologia Anatomica. Geschichte und Kritik der anatomischen Sprache der Gegenwart. Wien: Wilhelm Braumüller. K.K. Hof- und Universitätsbuchhändler. 